\title{
Musculoskeletal Findings, Connective and Soft Tissue Findings Link Identifier
}

National Cancer Institute

\section{Source}

National Cancer Institute. Musculoskeletal Findings, Connective and Soft Tissue Findings

Link Identifier. NCI Thesaurus. Code C162020.

A sequence of characters used as a linkage between related musculoskeletal system findings identifier records. 